\title{
Performance of Modified Natural Zeolites by Sodium Hydroxide Treatments in The Esterification of Glycerol and Oleic Acid
}

\author{
Rizky Achmad Fauzi ${ }^{1,2 *}$, Silvester Tursiloadi ${ }^{1}$, Adid Adep Dwiatmoko ${ }^{1}$, Dede \\ Sukandar $^{2}$, Fauzan Aulia ${ }^{1}$, Nino Rinaldi ${ }^{1}$, Sudiyarmanto ${ }^{1}$ \\ ${ }^{1}$ Recearch Center for Chemistry (RCC-Chem), Indonesian Institute of Sciences (LIPI) \\ PUSPIPTEK Serpong, Tangerang Selatan, Banten, Indonesia15314 \\ ${ }^{2}$ Chemistry Department, Science and Technology Faculty, UIN Syarif Hidayatullah Jakarta \\ Jl. Ir. H. Djuanda No. 95, Ciputat, Tangerang Selatan, Banten, Indonesia 15412 \\ "Corresponding author: rafauzi16@gmail.com
}

Received: April 2018; Revision: July 2018; Accepted: February 2019; Available online: November 2019

\begin{abstract}
Abstrak
Esterifikasi merupakan reaksi pembentukan senyawa ester dengan mereaksikan suatu senyawa alkohol dan asam karboksilat. Pada studi ini, kinerja katalis berbasis zeolit telah dipelajari untuk reaksi esterifikasi. Modifikasi ukuran pori zeolit dilakukan agar menjadi hierarchical zeolite, dengan tujuan untuk meningkatkan sifat katalitik zeolit. Modifikasi dilakukan secara desilikasi yaitu dengan perlakuan natrium hidroksida dengan variasi $0.1 ; 0.3 ; 0.5$ M. Katalis yang dihasilkan selanjutnya dikarakterisasi menggunakan BET dan XRD.Selanjutnya, katalis di uji aktifitasnya untuk reaksi esterifikasi asam lemak dan gliserol dan produk hasil dilakukan analisis menggunakan GC-MS. Modifikasi zeolit dengan natrium hidroksida yang dilakukan terbukti meningkatkan performa katalis, tanpa merubah struktur kristalnya. Aktivitas katalitik terbaik diperoleh pada katalis dengan perlakuan natrium hidroksida sebesar $0.3 \mathrm{M}$, dengan konversi sebesar $92 \%$ dan selektivitas ke produk monogliserida sebesar $74 \%$.
\end{abstract}

Kata kunci: Esterifikasi, zeolit, desilikasi, asam oleat, monogliserida.

\begin{abstract}
Esterification is the reaction of the formation of an ester compound by reacting an alcohol compound and carboxylic acid. In this study, the performance of zeolite-based catalysts has been studied for esterification reactions. Modification of zeolite pore size was done to be hierarchical zeolite, with the aim of increasing the catalytic properties of zeolite. The modification was carried out by desilication by sodium hydroxide treatment with a variation of $0.1 ; 0.3 ; 0.5 \mathrm{M}$. The resulting catalyst was then characterized using BET and XRD. Furthermore, the catalyst was tested for activity for esterification of fatty acids and glycerol and the product was analyzed using GC-MS. Zeolite modification with sodium hydroxide has been proven to improve catalyst performance, without changing their crystal structure. The best catalytic activity was obtained on the catalyst with sodium hydroxide treatment of $0.3 \mathrm{M}$, resulting glycerol conversion of $92 \%$ and selectivity to monoglycerides of $74 \%$.
\end{abstract}

Keywords: Esterification, zeolite, desilication, oleic acid, monoglyceride.

DOI: $10.15408 / j k v . v 5 i 2.9976$

\section{INTRODUCTION}

Monoglyceride, a class of glycerides with one molecule of glycerol linked to a fatty acid bound in an ester bond. Monoglycerides give many benefits in various industrial fields (Corma et al., 2005). They work as an emulsifier and an antimicrobial additive in the food industry (Setianto et al., 2017). Monoglycerides are obtained through the esterification or transesterification process, by reacting fatty acids or their methyl esters with glycerol in the presence of catalysts (Tampubolon et al., 2010).

Commonly, esterification are carried 
out by using highly selective homogeneous acid catalysts. However, this type of catalyst is corrosive, toxic, difficult to separate from the product, and non-reusable (Viswanathan and Rasmaswamy, 2007). In addition, homogeneous catalysts requires purification process which increases production costs (Fregolente et al., 2007). On the other hand, enzyme-based catalysts has been developed to produce monoglycerides with high yield, but it is less efficient due to high costs non-reusable (Rakorar et al., 2017). To deal with these problems, heterogeneous catalysts is more attractive.

Zeolite is one of heterogeneous acid catalysts which is commonly studied for the esterification. Chung and Park (2009) used ZSM-5 and mordenite to convert oleic acid into high yield of biodiesel with an optimum conversion of $80 \%$. Kartika and Widyaningsih (2012) used HCl-activated natural zeolite for the conversion of waste cooking oil into biodiesel with a conversion value of $100 \%$. Carmo et al., (2009) employed mesoporous zeolite (Al-MCM-41) for the esterification of palmitic acid to methyl palmitate with a conversion of 79\%. Setianto et al., (2017) used dealuminated-zeolite to synthesize glycerol monolaurate through esterification of glycerol with a conversion of $97 \%$ and yield of $59 \%$. In general, zeolites have pores with a micro size $(<2 \mathrm{~nm})$, so the catalysis reaction occurs mainly on the surface of the pore (Hermida et al., 2017). In addition, large size of substrate has potential to cause coke, thus shortening the life of the catalyst. Meanwhile, larger pore size catalysts provides bigger active sites inside their pores, therefore, higher conversion value can be obtained (Da Silva-Machado et al., 2000). For this reason, modification of natural zeolite by desilication using sodium hydroxide was done in this study to obtain into hierarchical zeolite (meso/micropore zeolite).Pore property change is expected to increase the catalytic performance for esterification of glycerol with fatty acid to obtain monoglycerides.

\section{MATERIALS AND METHODS Catalyst Preparation}

A total of $20 \mathrm{~g}$ of natural zeolite was mixed with $400 \mathrm{~mL}$ of sodium hydroxide with various concentrations $(0.1 \mathrm{M} ; 0.3 \mathrm{M}$; and 0.5 $\mathrm{M})$. The mixture was then stirred and heated at $75^{\circ} \mathrm{C}$ for $2 \mathrm{~h}$. The mixture was then neutralized using aquadest until neutral, then followed by filtration. The obtained solid were then washed repeatedly with distilled water until the filtrate became neutral, and then dried in an oven at $100{ }^{\circ} \mathrm{C}$ overnight. The zeolite was then activated using $\mathrm{NH}_{4} \mathrm{Cl}$ (1 M, E-Merck, p.a.) for $8 \mathrm{~h}$. Activated zeolite was then washed using aquadest until to remove chloride ions. Next, the zeolite was calcined at $550{ }^{\circ} \mathrm{C}$ for $2 \mathrm{~h}$. The characterization was carried out using the $\mathrm{N}_{2}$ physisorption and XRD analysis (Xiao and Wang, 2015). The obtained catalysts were assigned as Z, Z-0.1, Z-0.3, and Z-0.5.

\section{Catalytic Activity Test}

Oleic acid (technical grade), glycerol (E-Merck, p.a.), and catalyst $(0.7 \% \mathrm{w} / \mathrm{w})$ were put into a $250 \mathrm{~mL}$ round flask with a molar ratio of 1: 1 . The mixture was then refluxed at $180{ }^{\circ} \mathrm{C}$ with stirring for $3 \mathrm{~h}$. After the reaction, liquid product was then derivatized by mixing $50 \mu \mathrm{L}$ of product with $50 \mu \mathrm{L}$ of $\mathrm{N}$, O-Bis (trimethylsilyl) trifluoroacetamide (SigmaAldrich, p.a.), then heated to $70{ }^{\circ} \mathrm{C}$, then cooled and added $350 \mu \mathrm{L}$ dichloromethane (E- Merck, p.a.). Subsequently the samples were analyzed using GC-MS (Hachemi et al., 2017). Conversion (C) and product selectivity (MS) were calculated as follows:

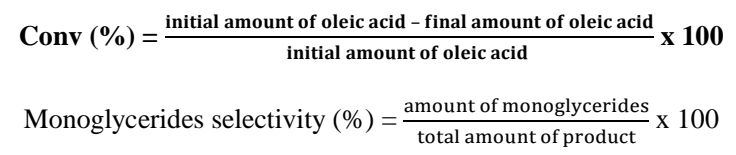

\section{RESULTS AND DISCUSSION Catalyst Characterizations}

Modified zeolites were characterized by $\mathrm{N}_{2}$ physisorption to measure their surface area, pore volume, and pore diameter. Adsorptiondesorption isotherm of the catalysts is shown in Figure 1. Unmodified zeolite shows a type V isotherm with hysteresis $\mathrm{H} 3$, indicating that the catalyst has a mesoporous type with weak interactions (Kajama et al., 2015). While the modified zeolites after treatment (Z-0.1; Z-0.3; and Z-0.5) shows isotherm type IV with H3 loop hysteresis type (Kajama, Nwogu et al., 2015). According to Thommes et al., (2015), this type of isotherm is a typical for mesoporous material with hysteresis, which are given by mesoporous adsorbents (for example, many oxide gels, industrial adsorbents and mesoporous molecular sieves). Adsorption behavior in mesoporous is determined by the adsorption interaction of 
adsorbents and also by interactions between molecules (Thommes et al., 2015). In this case, the initial monolayer-multilayer adsorption in the mesoporous wall is followed by pore condensation which is a phenomenon where a gas condenses into a liquid-like phase in the pore at $\mathrm{P}$ pressure less than the saturated pressure Po from the gas (Thommes et al., 2015). The results shown in Table 1 support the isotherm graph analysis. Based on the pore distribution curve based on the SF method (Fig. $1 b$ ), it was found that there was a significant increase in mesoporous distribution in the range of 4-15 nm. This is consistent with the reported results in the literature (Wei et al., 2006).

Untreated zeolite showed surface area of $22.9 \mathrm{~m}^{2} / \mathrm{g}$ with pore diameter range of $10-18 \mathrm{~nm}$ (Table 1). Meanwhile, the surface area of modified zeolites increased significantly, but the pore diameter experienced a wider distribution range. According to Nuryoto et al., (2016), development of pore distribution is due to the growth of small pores caused by the removal of zeolite constituent mineral components (desilication) (Wei et al., 2006).

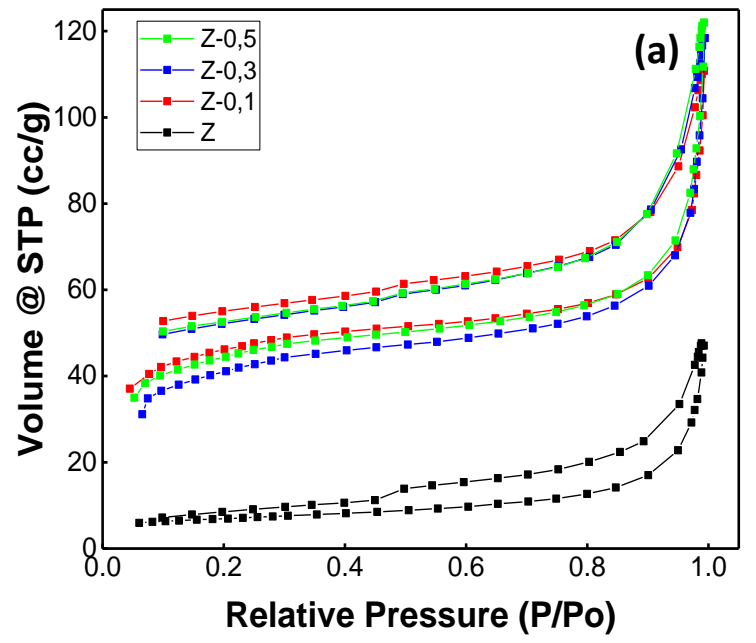

After modification with alkaline treatment, the natural zeolites transforms into hierarchical zeolite forms, indicated by the additional formation of surface area and microand mesopores volume. It was found that the micropores volume of modified zeolite were $0.00512 ; 0.0404 ; 0.0412 \mathrm{ml} / \mathrm{g}$ for Z-0.1, Z-0.3, and Z-0.5, respectively. While, the mesopores volume were $0.1202 ; 0.1427$; and $0.1475 \mathrm{ml} / \mathrm{g}$ for Z-0.1, Z-0.3, and Z-0.5, respectively. In addition, the surface area of the modified zeolites were $51.2 ; 61.2 ;$ and $64.2 \mathrm{~m}^{2} / \mathrm{g}$. It can be concluded that as the concentration of sodium hydroxide increases, external surface area and mesopores volume improve. This is similar with the results by Wang et al., (2015).

Powder XRD analysis of the zeolites are presented in Figure 2. The structure of the zeolites are mordenite, which can be seen from the diffractogram peaks at $2 \theta=9.79^{\circ} ; 13.45^{\circ}$; $22.29^{\circ} ; 26.60^{\circ}$ and $27.65^{\circ}$ (JCPDS No. 29-1257). In addition, it can be clearly seen that there was no change in the crystal structure of the sample after modification (Wei et al., 2006).

Figure 1. (a) Adsorption-Desorption Isotherm and (b) Pore Distribution based on SF Methods

Table 1. Characterization results using $\mathrm{N}_{2}$ physisorption

\begin{tabular}{cccccccc}
\hline Catalyst & $\mathbf{S}_{\text {BET }}{ }^{\mathbf{a}}\left(\mathbf{m}^{2} / \mathbf{g}\right)$ & $\mathbf{V}_{\text {total }}{ }^{\mathbf{b}}(\mathbf{m l} / \mathbf{g})$ & $\mathbf{D}_{\text {Pore }}{ }^{\mathbf{c}}(\mathbf{n m})$ & $\mathbf{V}_{\text {Micro }}^{\mathbf{b}}(\mathbf{m l} / \mathbf{g})$ & $\begin{array}{c}\mathbf{V}_{\text {Meso }} \\
(\mathbf{m l} / \mathbf{g})\end{array}$ & $\mathbf{S}_{\text {Micro }}{ }^{\mathbf{b}}\left(\mathbf{m}^{2} / \mathbf{g}\right)$ & $\mathbf{S}_{\text {ext }}\left(\mathbf{m}^{2} / \mathbf{g}\right)$ \\
\hline $\mathrm{Z}$ & 22.9 & 0.0728 & $10-18$ & - & - & - & - \\
$\mathrm{Z}-0.1$ & 148.2 & 0.1714 & $6-18$ & 0.0512 & 0.1202 & 97.1 & 51.2 \\
$\mathrm{Z}-0.3$ & 137.1 & 0.1831 & $4-15$ & 0.0404 & 0.1427 & 75.9 & 61.2 \\
$\mathrm{Z}-0.5$ & 145.5 & 0.1887 & $4-15$ & 0.0412 & 0.1475 & 81.4 & 64.2 \\
\hline
\end{tabular}

${ }^{\mathrm{a}} \mathrm{N}_{2}$ adsorption (according to BET method)

${ }^{\mathrm{b}} \mathrm{N}_{2}$ adsorption (according to $t$-method method)

c pore size distribution (according to SF method) 


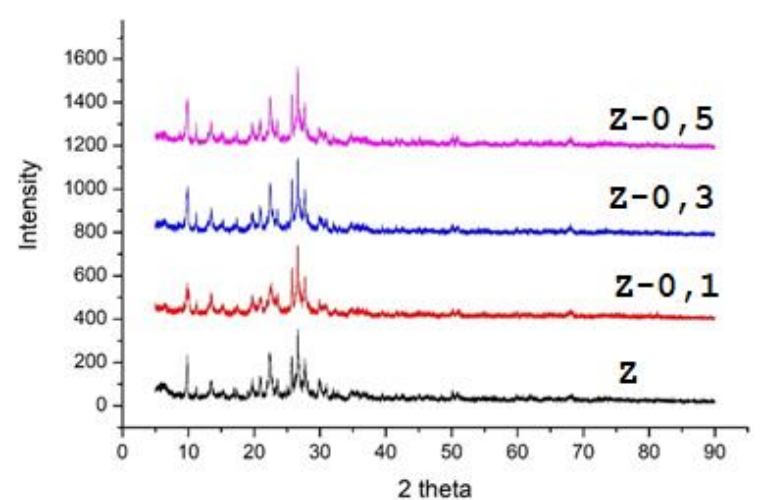

Figure 2. Powder XRD analysis of the prepared zeolites

\section{Catalytic Activity of the Prepared Catalyst}

Esterification of glycerol with oleic acid over various catalyst (unmodified natural zeolite, $\mathrm{Al}_{2} \mathrm{O}_{3}, \mathrm{TiO}_{2}$ ) was carried out using reflux with a ratio of $1: 1$ at $180{ }^{\circ} \mathrm{C}$ for $3 \mathrm{~h}$. The results are presented in Table 2. It is known that the zeolite showed moderate activity with conversion of $62.3 \%$, which was higher than $\mathrm{TiO}_{2}$ and $\mathrm{Al}_{2} \mathrm{O}_{3}$ with conversion values of 57.3 and $57.1 \%$, respectively. However, the zeolites showed the lowest selectivity among others. It can be concluded that natural zeolites have activity in the reaction of esterification of fatty acids and glycerol to monoglycerides

Table 2. Results of esterification reaction over various type of catalysts

\begin{tabular}{lcc}
\hline \multicolumn{1}{c}{ Catalyst } & $\begin{array}{c}\text { Conversion } \\
(\%)\end{array}$ & $\begin{array}{c}\text { Monoglycerides } \\
\text { Selectivity (\%) }\end{array}$ \\
\hline $\begin{array}{l}\text { Natural } \\
\text { zeolites }(\mathrm{Z})\end{array}$ & 62.3 & 74.1 \\
$\mathrm{Al}_{2} \mathrm{O}_{3}$ & 57.1 & 80.3 \\
$\mathrm{TiO}_{2}$ & 57.3 & 82.9 \\
\hline
\end{tabular}

Furthermore, catalytic activities of modified zeolites using sodium hydroxide was presented in Table 3. It can be seen that oleic acid conversion were altered after the zeolites were treated using sodium hydroxide. There was an increase in the oleic acid conversion and monoglycerides selectivity for all modified zeolites. The conversion for Z-0.1; Z-0.3; and Z0.5 were $71.4 ; 92.0$; and $68.4 \%$, respectively. Selectivity of monoglycerides also increases, following the concentration of sodium hydroxide. The selectivity of monoglycerides over Z-0.1; Z0.3 ; and Z-0.5 were 63.8; 74.8; and $78.9 \%$, respectively. These catalytic improvement in terms of conversion and monoglycerides selectivity could be related with the increase of zeolites pore size, in which the alteration of micropores to mesopores, which results the improvement of reactant accessibility to reach catalyst active sites and the improvement of monoglyceride accessibility to diffuse out of the catalyst (Zhong et al., 2013).

Table 3. Esterification reaction results over modified zeolites

\begin{tabular}{ccc}
\hline Catalyst & $\begin{array}{c}\text { Conversion } \\
(\boldsymbol{\%})\end{array}$ & $\begin{array}{c}\text { Monoglycerides } \\
\text { Selectivity }(\boldsymbol{\%})\end{array}$ \\
\hline $\mathrm{Z}$ & 62.3 & 74.1 \\
Z-01 & 71.4 & 63.8 \\
Z-03 & 92.0 & 74.8 \\
Z-05 & 68.4 & 78.9 \\
\hline
\end{tabular}

In addition, a large pore size also allows for monoglycerides to diffuse back into the reactant solution, then diffusion of the product will be difficult so that reactant accessibility will be inhibited and the conversion will be reduced (Zhong et al., 2013). As seen from the table there was a decrease in zeolite conversion with $0.5 \mathrm{M}$ sodium hydroxide treatment, which was due to the high microporosity on the zeolite. According to Abdullah et al. (2015), high microporosity decreased the conversion of the acids microporosity from $64 \%$ to $29 \%$, as observed from monoglyceride formation from lauric acid over the catalyst with high microporosity. Micropores increases the selectivity to monoglycerides, by reducing the possibility of large molecules formation, such as di- and triglycerides (Alvarez et al., 2004). From our results, it is found that the highest conversion was achieved by the zeolite modified with $0.3 \mathrm{M}$ of sodium hydroxide, where for the zeolite it has a large pore diameter of $5.34 \mathrm{~nm}$. It can be concluded that he pore diameter is getting bigger and the mesoporosity surface which can increase the conversion value and the selectivity value of the monoglyceride esterification reaction results.

The results of product analysis using GC-MS are presented in Table 4. It can be seen that the products formed from the reaction can be classified into three groups, namely monoglycerides, fatty acids and others. Monoglycerides include 1-monoolein, 2monoolein, glycerol monostearate and glycerol monopalmitate. Fatty acids were detected after the reaction, including palmitic acid, stearic acid 
and myristic acid. These fatty acids conceivably come from oleic acid impurities (technical grade). Meanwhile, other products such as isobutanol, 1-propanol, and several unidentified compounds were also detected.

Table 4. Analysis of reaction products using GC-MS

\begin{tabular}{ll}
\hline Group & \multicolumn{1}{c}{ Products } \\
\hline Monoglycerides & 1-Monoolein \\
& 2-Monoolein \\
& Glycerol Monostearate \\
& Glycerol Monopalmitate \\
Fatty acids $\left.{ }^{*}\right)$ & Palmitic acid \\
& Myristic acid \\
& Stearic acid \\
Others & Isobutanol \\
& 1-Propanol \\
& Unidentified products \\
\hline${ }^{*}$ possibly from the impurities of oleic acid (technical grade)
\end{tabular}

\section{Effects of Temperature on The Esterification Over Modified Zeolites}

Effects of reaction temperature on the esterification reaction over Z-0.3 catalyst was studied at 140,160 , and $200{ }^{\circ} \mathrm{C}$ for $3 \mathrm{~h}$, and the results are shown in Table 5. It can be seen that increasing reaction temperature improved the conversion, in which the conversion at 140, 160, 180 and $200{ }^{\circ} \mathrm{C}$ were $27.9 ; 39.7 ; 92.0$; and $86.1 \%$, respectively. This was followed by the increase of selectivity to monoglycerides, in which the selectivity at 140, 160, 180 and $200{ }^{\circ} \mathrm{C}$ were $52.1 ; 71.6 ; 74.9$; and $77.3 \%$, respectively. The increase of temperature causes improvement of reaction rate to anticipate activation energy (Ratchadapiban et al., 2018).

Table 5. Esterification results over modified zeolites $\mathrm{Z}-0.3$ at different reaction temperature

\begin{tabular}{ccc}
\hline $\begin{array}{c}\text { Reaction } \\
\text { Temperature } \\
\left({ }^{\circ} \mathbf{C}\right)\end{array}$ & $\begin{array}{c}\text { Conversion } \\
(\boldsymbol{\%})\end{array}$ & $\begin{array}{c}\text { Monoglycerides } \\
\text { Selectivity }(\%)\end{array}$ \\
\hline 140 & 27.9 & 52.1 \\
160 & 39.7 & 71.6 \\
180 & 92.0 & 74.9 \\
200 & 86.1 & 77.3 \\
\hline
\end{tabular}

At a temperature of $200{ }^{\circ} \mathrm{C}$, the conversion of oleic acid decreased to $86.1 \%$. This presumably caused from the reaction equilibrium has been achieved at $180{ }^{\circ} \mathrm{C}$. According to Patel and Singh (2014), the reaction temperature affects reaction rate equilibrium faster, so that, the equilibrium has been reached before 3 hours at $200{ }^{\circ} \mathrm{C}$. The increase in reaction temperature also affects the physical properties of the product, wherein the product produced at higher temperatures has a darker color compared to products at lower temperatures. According to Hermida et al., (2011), darker color was due to the degradation of oleic acid and glyceride molecules at higher temperature.

\section{CONCLUSION}

In this work, the performance of zeolite-based catalysts for the esterification reaction has been studied. Modification of zeolite with sodium hydroxide has been proven to improve catalyst performance, without changing its structure. The best activity was obtained on the catalyst with sodium hydroxide treatment of $0.3 \mathrm{M}$, with a conversion of $92 \%$ and selectivity to a monoglyceride product of $74 \%$. Further detailed studies are needed to fully understand the cause of the increased catalytic performance after modification. However, the results of this preliminary study can be used as a basis for the development of zeolite-based heterogeneous catalysts for glycerol esterification.

\section{ACKNOWLEDGEMENTS}

Authors thank the Ministry of Research and Technology and Higher Education (Kemenristekdikti), which provided funding through the INSINAS Program-LIPI Flagship, with Field of Research: Development of Functional Food Based on Local Resources. Authors also appreciate the Research Center for Chemistry and the Research Center for Physic, Indonesian Institute of Sciences (LIPI) for providing of research facilities for analysis and characterizations.

\section{REFERENCES}

Carmo CMJ, Souza LKC, Costa CEF, Longo E, Zamian JR, Filho GNR. 2009. Production of biodiesel by esterification of palmitat acid mesoporous aluminosilicate AlMCM-41. J Fuel. 88: 461-468.

Chung KH, Park BG. 2009. Esterification of oleic acid in soybean oil on zeolite catalysts with different acidity. Journal of Industrial 
and Engineering Chemistry. 15(3): 388392.

https://doi.org/10.1016/j.jiec.2008.11.012

Corma A, Hamid SBA, Iborra S, Velty A. 2005). Lewis and Brönsted basic active sites on solid catalysts and their role in the synthesis of monoglycerides. Journal of Catalysis. $\quad 234(2): \quad 340-347$. https://doi.org/10.1016/j.jcat.2005.06.023

Da Silva-Machado M, Pérez-Pariente J, Sastre E, Cardoso D, De Guerenu, A. Selective synthesis of glycerol monolaurate with zeolitic molecular sieves. Appl Catal A Gen 2000b. 203: 321-328.

Feliczak-Guzik A. 2018. Hierarchical zeolites: Synthesis and catalytic properties. Microporous and Mesoporous Materials. 259: 33-45. https://doi.org/10.1016/j.micromeso.2017. 09.030 .

Fregolente LV, Fregolente PBL, Chicuta AM, Batistella CB, Filho RM, Wolf MMR. 2007. Effect of operating conditions on the concentration of monoglycerides using molecular distillation. J. Chemical Engineering Research and Design. 85: 1524- 1528 .

Haag WO, Lago RM, Weisz PB. 1984. The active site of acidic aluminosilicate catalysts. Nature. 309: 589-591.

Hasenhuettl GL, Hartel RW. 2008. Food Emulsifiers and Their Aplications. (G. L. Hasenhuettl \& R. W. Hartel, Eds.) (Second). Springer Science+Business Media, LLC. https://doi.org/10.1007/9780-387-75284-6.

Hermida L, Amani H, Saeidi S, Zuhairi AA, Rahman MA. 2017. Selective acidfunctionalized mesoporous silica catalyst for conversion of glycerol to monoglycerides: state of the art and future prospects. Reviews in Chemical Engineering. https://doi.org/10.1515/revce-2016-0039.
Kajama MN, Nwogu NC, Gobina E. 2015. Hydrogen permeation using nanostructured silica membranes. Witpress. 193: 447-456.

Lee DW, Park YM, Lee KY. 2009. Heterogeneous base catalysts for transesterification in biodiesel synthesis. Catal Surv Asia. 13: 63-77.

Pagliaro M, Rossi M. 2008. The Future of Glycerol: New Uses of a Versatile Raw Material. RSC Green Chemistry Book Series.

Rarokar NR, Menghani S, Kerzare D, Khedekar PB. 2017. Journal of Experimental Food Progress in Synthesis of Monoglycerides for Use in Food and Pharmaceuticals. 3(3): 1-6. https://doi.org/10.4172/24720542.1000128 .

Setianto WB, Wibowo TY, Yohanes H, Illaningtyas F, Anggoro DD. 2017. Synthesis of glycerol mono-laurate from lauric acid and glycerol for food antibacterial additive Synthesis of glycerol mono-laurate from lauric acid and glycerol for food antibacterial additive. IOP Conf. Series: Earth and Environmental Science. 65(2017): 012-046

Viswanathan B, Ramaswamy AV. 2007. Selection Of Heterogeneous Catalysts For TransEsterification Reaction, Indian Institute Of Technology, Madras, Chennai 600036.

Wang F, Xiao G. 2015. Performance of hierarchical HZSM-5 zeolites prepared by Sodium hydroxide treatments in the aromatization of glycerol. The Royal Society of Chemistry. https://doi.org/10.1039/b000000x .

Wei X, Smirniotis PG. 2006. Development and characterization of mesoporosity in ZSM12 by desilication. Microporous and Mesoporous Materials. 97(1-3): 97-106.

Zhong N, Cheong LZ, Xu X. 2013. Strategies to obtain high content of monoacylglycerols. European Journal of Lipid Science and Technology. 116(2): 97-107. 